\title{
COMMUNITY-BASED TOURISM IN THE CASE OF THE MALDIVES
}

\author{
Andrea GIAMPICCOLI \\ Durban University of Technology, Ritson Campus, Department of Hospitality and Tourism \\ PO Box 1334, Durban, 4000, South Africa, e-mail: andrea.giampiccoli@gmail.com

\section{Basma ABDUL MUHSIN} \\ Centre for Higher Secondary Education, Lily Magu, Male', Maldives, \\ e-mail: basmamuhsin@gmail.com

\section{Oliver MTAPURI*} \\ University of Limpopo, Department of Research Administration and Development, \\ University Street, Turfloop, Sovenga 0727, Limpopo, e-mail: simbaomtapuri@yahoo.com
}

\begin{abstract}
Citation: Giampiccoli, A., Abdul Muhsin, B. \& Mtapuri, O. (2020). COMMUNITY-BASED TOURISM IN THE CASE OF THE MALDIVES. GeoJournal of Tourism and Geosites, 29(2), 428-439. https://doi.org/10.30892/gtg.29204-479

Abstract: This article aims at analyzing tourism development efforts in the guesthouse sector in the Maldives. In terms of method, it is a conceptual paper, which is based on a systematic literature review. The results show that tourism in the Maldives is dominated by foreign controlled resorts explaining the unequal distribution of its benefits. Entrepreneurs can focus on community guesthouses to cater for a 'budget' market as well as high-end tourists. The article suggests that the Madives must create CBT ventures through decentralizing to a greater number of islands/atolls and redistributing resources to decrease inequality of control and benefits.
\end{abstract}

Key words: $x$ tourism, community-based tourism, Maldives, Small states, Islands, SIDS

\section{INTRODUCTION}

Tourism is a growing industry in Small Island Developing States (SIDS). For instances, in the Maldives, in 2016 "tourism contributed a total of 14 million Rufiyaa which was 22.7\% of the total national GDP of the year" (Ministry of Tourism of Maldives - MTRM, 2017, 9). The Gross Domestic Product (GDP) of the Maldives was at an all-time high of US $\$ 5.27$ billion in 2018, which accounts for 0.01 percent of the global economy the lowest was US\$0.04 billion recorded in 1981 with an average of US $\$ 1.35$ billion between 1980 and 2018 (Trading Economics, 2019). Small islands destinations can be proactive and sensitive about their communities with respect to tourism development (Vogt, et al., 2016, 36). Their specific settings within precise geographic limits far from

\footnotetext{
* Corresponding author
} 
the mainland and the small populations create entrepreneurial opportunities to carve out distinctive cultural identities of well-knit societies necessarily aware of the impacts of tourism development on their well-being (Vogt et al., 2016). Tourism is important for SIDS because of their location, physical features, flora and fauna which combined present a unique proposition to create a visitors' paradise by virtue of their islandness.

Tourism as a sector can have negative and positive impacts on communities (Nagarjuna, 2015, 14). Thus, the need to involve local communities in various aspects of tourism development and benefits is well recognised (Nagarjuna, 2015, 14; Salleh et al., 2016, 565; Burgos et al., 2017, 546; Rasoolimanesh \& Jaafar, 2016, 5).

In fact, community participation is vital for enhancing the quality of the contribution of tourism to the national economy. This involvement of indigenous communities usually of low income in both urban and rural areas means that these groups of people will have found a platform to engage with government from which they are often excluded (Novelli \& Gebhardt, 2007, 449). This suggests that disadvantaged members of society should be targeted when referring to community involvement as this will allow them to be involved in the technologies of governance. It can also be argued that this is important for inclusivity. We advocate for inclusive tourism which we define as any form of tourism that involves a majority of the people (particularly the disadvantaged communities) for the betterment of their communities while ensuring the preservation and protection of the environment for future generations.

Community-Based Tourism (CBT) is a type of tourism development that aims to counteract the negative impacts of conventional/mass tourism (Gadi Djou et al., 2017, 16). It is growing in popularity (Mearns \& Lukhele, 2015, 2) and it is specifically intended for disadvantaged members in society (Tasci et al., 2013, 10). Most of the benefits should go to the people who make tourism happen in their localities - the small local operators. This is a necessary imperative to grow local economies and providing employment and incomes for local people through their own entrepreneurship.

A growing middle class is necessary so that the inequalities do not widen. When people have their own incomes, they rely less on government support programmes as they can fend for themselves. The participation of people is important for them to realise their own ambitions and enhance their feeling of being citizens of their country as they choose to do the things which they like. The reduction of poverty is important particularly in the context of the Sustainable Development Goals which aspire to eradicate poverty by 2030. The article proposes that a CBT approach to entrepreneurship for tourism development is a better option moving forward. In this context, the article will propose a model of tourism development which leans towards CBT.

\section{LITERATURE REVIEW}

The specific geography, natural and cultural resources of SIDS make them unique but vulnerable ecosystems. This also applies to the Maldives particularly because tourism is the main economic activity across 1190 islands within 26 natural atolls. Tourism exposes the vulnerabilities of these islands when viewed from the perspective of small-island sustainability particularly because small islands suffer high (financial) leakages as a consequence of dependence on imported goods and the propensity of the industry to employ foreign staff especially at higher organizational levels (TwiningWard \& Butler, 2002, 363). SIDS should address the issues of financial leakages as a collective as individually they may not possess the wherewithal to face these strong, well-networked corporations involved in these practices. The fragility of their environments requires concerted efforts in managing tourism to their benefit - this may require that environmental conservation and protection practices and standards 
are harmonised in circumstances where these are informed by best practice (without undermining the sovereignty of individual states). Besides threats to the natural environment, the other challenge afflicting the SIDS is the foreign ownership of the industry (Briguglio \& Briguglio, 2004, 1). For instance, incoming tourists are under the control of foreign tour operators with enormous bargaining power to definitively pronounce on matters in the host country and larger operators in SIDS are foreign and pursue their own agenda at the expense of the interests of host countries (Briguglio \& Briguglio, 2004, 2). These issues of foreign control can well enter the debate regarding tourism and imperialism (Sinclair-Maragh \& Gursoy, 2015, 146) in which imperialism is capitalism that is interested in expanding the market for private gain.

Within imperialism which represents a "disharmony paradigm, there are opposing interests between foreign investors and the host country" (Sinclair-Maragh \& Gursoy, 2015, 146). In this context two discourses are evident, one says foreign companies benefit the most from profits generated at the expense of locals and the second says investors and locals do not have the same expectations from the investments such that foreign investors expect profit while host countries expect to absorb the capital and technology brought by the investment (Sinclair-Maragh \& Gursoy, 2015, 146). A UNDP/World Bank Vulnerability and Poverty Assessment showed that households with a member working in tourism are more likely to be nonpoor but "only $15 \%$ of employed Maldivian men and $4 \%$ of employed Maldivian women work in the sector [ ...] The lack of opportunities at the managerial level deters many Maldivians from participating in tourism" (MOTAC, 2013b: 185). Deliberate actions by governments should be taken to reverse these patterns in which local people are not adequately benefiting from the national economy. Additional measures need to be put in place in terms of adoption of new telecommunication technologies if these states are to fully participate and benefit from the Fourth Industrial Revolution.

\section{COMMUNITY-BASED TOURISM}

The root of CBT dates back to 1970 s when discourses of alternative development approaches that include matters of empowerment, sustainability, social justice and selfreliance were flourishing and CBT was intended for disadvantaged community members (Giampiccoli, 2015). Thus, CBT is directed to favor community development in "remote, rural, impoverished, marginalized, economically depressed, undeveloped, poor, indigenous, ethnic minority, and people in small towns" (Tasci et al., 2013, 10).

Community-based tourism "aims to the holistic goal of empowering underprivileged groups sustainably" (Tasci et al., 2013, 84). In this context CBT in Maldives should be intended for poorest and social-economically and geographically (atolls) marginalized section of the Maldivian population. Community-based tourism denotes a type of tourism that is "managed and controlled by the community' (Leksakundilok \& Hirsch, 2008, 214) and it "can empower local communities, giving them a sense of pride in their natural resources and control over their communities' development" (Mearns, 2012, 72). The main objective of CBT is local development for the long haul with benefits accruing to many social actors and not a few entrepreneurs (Mano et al., 2017, 417). It is important to note that CBT is not in any way inferior to mainstream tourism (Ndlovu et al., 2011), it is just another type of tourism. While usually small scale, CBT can be up-scaled and can be implemented in large hotels and infrastructure which means that it can expand to cover most, if not the whole tourism sector of a specific area and thus become the area's main (or only) tourism approach. As such from being small scale it can become the mainstream tourism sector in a given locality. Small scale operations do create jobs and provide incomes for operators. 
CBT cannot be achieved easily in communities. Mtapuri \& Giampiccoli (2016) note that while CBT emerges organically from the bottom, it is rare for it to emerge without the support (for example, for marketing) of external partners as well as facilitation. It is in this context that the role of government is fundamental in providing such support, for example by SMME schemes or specific CBT capacity building programmes. Giampiccoli et al., (2014) maintain that Government's role is crucial for the promulgation of policy, empowerment and overall capacity building. Policies and strategies that are meant to transform economies can only be made by Government with other stakeholders. This cannot be left to the markets to address as markets can be manipulated to favour a few. Examples of this manifest in the way monopolies and oligopolies wield power in price determination protruding to colossal political influence when they capture states and governments. This paper posits a CBT approach as a specific strategic issue to be adopted to reduce poverty, facilitate holistic community development and shift tourism control and benefits towards local entrepreneurs in SIDS. In this paper we emphasize the role of Government, as do other writers, because it is only Government that has capacity to act in the interests of its people if it is a Government by the people for the people. Informality is evident especially in the early stages of CBT development or when CBT is left to grow on its own without any formal government support structure in place to guide and facilitate CBT development from the start.

\section{THE MALDIVES}

Tourism is the main economic sector in the Maldives. It is a huge foreign currency earner as well as being a huge employer in the country's tertiary sector (Kundur, 2012, 1). The role of tourism in Maldives came about after a short history in the country with a visit by a group of 22 tourists from Italy in the 1970s who were looking for 'untouched' tropical islands at which to vacation (at the time, tourism was packaged with Sri Lanka) but now it has grown to include all forms of holidaying associated with the 3'S's of Sun, Sea and Sand (MOTAC, 2013b, 10). The 3S's remain a huge attraction for the Maldives. Present day Maldives is a renowned, award-winning tourist destination with world-class, state of the art facilities as well as high-tech telecommunication services (Kundur, 2012).

Since the opening of the first resort in 1972, five phases of tourism development are evident in the Maldives (see Kundur, 2012). The growth in tourism has had its effects on the population and on Gross Domestic Products (GDP), thus, starting from 1972, the time of the establishment of the first resort, government managed to turn islands into high-end resorts and real GDP growth has averaged about $7.4 \%$ during the period 1986-2014 and achieved middle-income country status by 2011 with a relatively high GDP per capita among South Asian states (Asian Development Bank, 2015b, p.1). Growth must be inclusive to benefit many. Data on Maldives on Human Development show a mixed picture. Inequality remains a burden. The UNDP $(2016,4)$ notes that "Between 1995 and 2015, Maldives' HDI value increased from 0.520 to 0.701 , an increase of 34.8 percent [...] Maldives' progress in each of the HDI indicators" (UNDP, 2016, 2). The Maldives has the highest per capita income in South Asia and a relatively high Gini coefficient by sub-regional standards (Asian Development Bank, 2015b).

Vulnerability and high poverty rates persist in many islands due to a lack of opportunities for the disadvantaged in society (see Asian Development Bank, 2015b). Asian Development Bank (2015b) notes that growth is inclusive when many in society benefit from the opportunities that this growth creates while being cushioned from economic shocks. The World Bank (WB, 2015) report notes that the Maldivian growth model is not inclusive threatening its social, environmental and fiscal sustainability because of high levels of inequality and a sense of unshared prosperity Maldives exemplifies 
a typical dilemma faced by SIDS for relying on tourism for economic development, the benefits therefrom are not cascading to those most in need partly due to leakages. World Bank (2015) proposes that one possible action to remedy the situation is by opening up entrepreneurial opportunities for locals to participate in exiting industries. Tourism, as the main industry should certainly be at the forefront in adopting this suggestion because of its capacity to absorb even those with low skills and women in particular.

The participation of broader society in entrepreneurship will ensure the harnessing of the totality of local energies, synergies, capacities and resources to good use for the betterment of the lives of the people of the Maldives. It is the lives of the people that matter. Collaborations lessen the burden on a single party. It can be argued that the situation could be redeemed using legislation, for example, which offers various -but compulsory - solutions of partnerships. It is also important to understand that economic criteria should not be the only criteria applied in relation to weighing the benefits of tourism. This applies to all types of tourism, but especially true with respect to alternative tourism development. Beyond that, an evaluation of various local and global issues is also pertinent. While Maldives tourism is very sophisticated in the luxury segments it lags behind at community level when compared to other Asian countries (MOTAC, 2013a).

Debate is also present in relation to the differentiation and choice between the different accommodation typologies, to the extent that the FTMP (MOTAC, 2013b, 100) leaves it to the property owner (not the government) to decide whether his establishment is a guesthouse or a small boutique hotel and also notes that small boutique hotels have been the leading form in other Asian countries. In this context it exalts a situation in which tourist travel unbooked and to decide on the moment the accommodation possibly explaining the emergence of CBT in Asia (MOTAC, 2013b, 118). It is also possible to link boutique hotels to the CBT context leading to what has been termed luxury CBT (LCBT) (see Mtapuri \& Giampiccoli, 2017). Thus, CBT and its adaptation Luxury Community-based Tourism (LCBT) can be seen as a possible open market strategy worth adopting. Specific support, facilitation and regulation is seen necessary to advance LCBT. Low levels of education certainly pose challenges to tourism development in general and CBT in particular. While there is a Bachelor of Science in Hotel and Resort Management (MTAC, 2011), it does not offer any alternative tourism qualification such as CBT or sustainable tourism. The Maldives still face the challenge of providing quality education and churning out professionals, tertiary education and vocational graduates for a growing modern economy (Asian Development Bank, 2015b).

\section{RESULTS \\ Possible pathway for Maldives entrepreneurship and tourism development}

Based on the above, this section proposes a possible way forward for tourism development in Maldives to shift the tourism sector towards adopting CBT related characteristics or creating linkages to CBT ventures. This proposal is based on four related main factors, namely: the need to decentralize to a greater number of islands/atolls; the need to redistribute, thus to decrease inequality of control and benefits within society; the need to break dependency on externally controlled tourism businesses; and the need to increase greater varieties of tourism facilities linked to various market segments. Furthermore, it is proposed that each specific 'type of tourism' needs its own specific regulation. The new specific requirements in ownership, management structure and redistributive measures, environmental requirements and so on should be formulated for each tourism subject, for example, for each type of accommodation category as proposed above. Based on these factors, nine main guiding categories of 
accommodation emerge (this could apply also to other tourism businesses such as restaurants and so on). The categories are:

1. Conventional large private investment resort/hotel (Category A) - without any new specific requirements (as it is now)

2. Conventional large private investment resort/hotel (Category B) - with new specific requirements in ownership, management structure and redistributive measures, environmental requirements and so on

3. Partnership state and private sector resorts - with new specific requirements in terms of ownership, management structure and redistributive measures, environmental requirements and so on

4. Fully State owned and managed resort - also requires to have new specific requirements in ownership, management structures and redistributive measures, environmental requirements and so on

5. SMMEs (that is guesthouses, bed \& breakfasts and backpackers) foreign owned (Category A) - although not necessarily the same as CBT. This should also be organized in a similar fashion to CBT structures - without any new specific requirements (as it is now)

6. SMMEs (that is guesthouses, bed \& breakfasts and backpackers) foreign owned (Category B) - although not necessarily the same as CBT. This should also be organized on similar lines as a CBT structure - with new specific requirements in ownership, management structures and redistributive measures, environmental requirements and so on

7. SMMEs (that is guesthouses, bed \& breakfasts and backpackers) locally owned (Category A) - although not necessarily the same as CBT, this should also be organized on similar lines as CBT structures - without any new specific requirements (as it is now)

8. SMMEs (that is guesthouses, bed \& breakfasts and backpackers) locally owned (Category B) - although not necessarily the same as CBT, this should also be organized on similar lines as CBT structures - with new specific requirements in ownership, management structures and redistributive measures, environmental requirements and so on

9. CBT disadvantages atolls/islands and/or social groups - with new specific requirements in ownership, management structures and redistributive measures, environmental requirements and so on

9.1. CBT - community owned and managed resort

9.2. CBT - Individual establishment or ventures under a common umbrella organization

It is evident in Table 1 the three categories (number 1, 5, and 7) remain circumscribed by existing legislation and requirements, whereas all other categories require new specific requirements in ownership, management structures and redistributive measures, environmental requirements and so on. Irrespectively of the categories, these new requirements should also be based on business size and resources availability (Table 1). The nine types of accommodation establishments with their associate ownership and management structure should be able to coexist.

However, it is envisaged that there is a need to put in action a proper shift to rebalance the composition of the Maldivian tourism structures. Maximum effort should be made to attract investors into category 1, 5 and 7 to shift towards the respective 2, 6 and 8 categories with new specific requirements in ownership, management structures and redistributive measures, environmental requirements and so on. For example, category 1 (Conventional private investment resort/hotel - Category A) should fade away, by slowly decreasing in relevance so to enhance always more category 2 with new requirements. While new resort/hotels investors still can opt for category 1 specific attractive measures should favor the shift towards category 2 (Conventional private investment resort/hotel - Category B). Established Category 1 entities should also be attracted and facilitated by specific measures to transform themselves into Category 2 
resort. The aim should be to shift the tourism sector towards the adoption of new specific requirements in ownership, management structures and redistributive measures, environmental requirements and so on. It is recognized that most these new requirements will have to be legally binding but attractive incentives should be offered to investors.

Table 1. Main characteristics of accommodation categories

\begin{tabular}{|c|c|c|c|c|}
\hline Nr. & Category & \begin{tabular}{|c|} 
Actual \\
Legislation / \\
requirements
\end{tabular} & $\begin{array}{c}\text { New } \\
\text { Legislation / } \\
\text { requirements }\end{array}$ & Ownership \\
\hline 1 & $\begin{array}{l}\text { Conventional large private } \\
\text { investment resort/hotel } \\
\text { (Category A) }\end{array}$ & $\sqrt{ }$ & & $\begin{array}{l}\text { Foreign or local } \\
\text { Businesses }\end{array}$ \\
\hline 2 & $\begin{array}{l}\text { Conventional large private } \\
\text { investment resort/hotel } \\
\text { (Category B) }\end{array}$ & & $\sqrt{ }$ & $\begin{array}{l}\text { Foreign or local } \\
\text { Businesses }\end{array}$ \\
\hline 3 & $\begin{array}{c}\text { Partnership state and private } \\
\text { sector resorts }\end{array}$ & & $\sqrt{ }$ & $\begin{array}{l}\text { State and foreign } \\
\text { or local businesses }\end{array}$ \\
\hline 4 & $\begin{array}{c}\text { Fully State owned and } \\
\text { managed resort }\end{array}$ & & $\sqrt{ }$ & State owned \\
\hline 5 & $\begin{array}{l}\text { SMMEs - foreign owned } \\
\text { (Category A) }\end{array}$ & $\sqrt{ }$ & & Foreign businesses \\
\hline 6 & $\begin{array}{l}\text { SMMEs - foreign owned } \\
\text { (Category B) }\end{array}$ & & $\sqrt{ }$ & Foreign businesses \\
\hline 7 & $\begin{array}{l}\text { SMMEs - locally owned } \\
\text { (Category A) }\end{array}$ & $\sqrt{ }$ & & Local businesses \\
\hline 8 & $\begin{array}{l}\text { SMMEs - locally owned } \\
\text { (Category B) }\end{array}$ & & $\sqrt{ }$ & Local businesses \\
\hline 9.1 & $\begin{array}{c}\text { CBT - community own and } \\
\text { managed resort }\end{array}$ & & $\sqrt{ }$ & $\begin{array}{c}\text { Disadvantaged community } \\
\text { members }\end{array}$ \\
\hline 9.2 & $\begin{array}{c}\text { CBT - Individual establishmen } \\
\text { or ventures under common } \\
\text { umbrella organization }\end{array}$ & & $\sqrt{ }$ & $\begin{array}{l}\text { Disadvantaged community } \\
\text { members }\end{array}$ \\
\hline
\end{tabular}

There is the need to develop new forms of incentives which are legally binding and are modelled towards effecting structural change in the tourism sector itself such as in shareholding of the business, benefits with the employees and local community members, the (legal) inclusion of employees and local community members in decision making and so on. This implies that for a private investment in resort Category 2 - a number of proposals can be advanced regarding shareholding agreements. Legally binding shareholding requirements can be drawn in which the employees and/or local people living in the nearest island should share ownership and management of the resort and its immediate surroundings and geographical context together with private investors.

Using resorts as example, if a resort gives - for example $-5 \%$ ownership/benefits to employees or local community, a specific tax relief could be applied. Various contexts will have to have specific solutions and incentives, however all should remain directed towards the above proposed substratum factors undergirded by the need to decentralize to a greater number of islands/atolls; the need to redistribute, thus decrease the inequality in tourism control and benefits within society; the need to break the dependency on externally controlled tourism businesses; and the need to increase the varieties of tourism facilities linked to various market segments. Various possible options are present such as employees and community forming a cooperative, a trust or similar entity together or separately and these entity(ies) co-own and co-manage the resort. A 
possible scale of ownership could be developed where at each level, specific incentives are given to the private investors (however these incentives still have to remain within the new proposed parameters needed for Category 2). While these incentives/concessions could be seen by some critics as a new type of 'race to the bottom' competition, to the contrary, the employees and immediate closest community will share the benefits of the resort. It is important, to note that this shareholding system should not produce a dependency-like situation in which the local community and employees just get 'free' money for doing nothing. Local community members are also obliged to have their share of participation/work. A framework of community and employee participation must be formulated and monitored by private investors, government and civil society.

New research and new approaches can certainly find other innovative ways related to shareholding. The bottom line is that the resort and the employees and local community should work together for mutual benefit, as the benefits to employees and local community become a direct arrangement and a direct effect. Certainly this proposal could be used by more radical social entrepreneurs through their Corporate Social Responsibility (CSR) programmes. In addition, while the global competitive environment is recognized new attractive incentive can be devised to encourage investment that are not as usual tax relief or labour and environmental related but new ones related to loosening regulations in the banking system or communication networks.

The nine categories should be balanced by giving each category a specific quota in order to proportionally cater for a greater variety of tourism markets and facilitate a more redistributive and environmentally friendly approach to tourism development. These new categories of establishments should also be understood and be located within a framework of the tourism sector in relation to CBT (see Figure 1). It illustrates various accommodation types and should be read (in line with the category list above). It shows how all these different accommodation type establishments could be linked to CBT and it also includes a CBT organization as a central feature to coordinate and facilitate CBT in Maldives. Essentially resorts, hotels and safari vessels should be able to partner with specific CBT ventures, the CBT organization, and other community activities.

Given the importance of the accommodation sector, it is proposed that partnerships with other community activities should be supported but being subordinated to partnerships with CBT accommodation and the CBT organization. For example, a specific requirement for Category 2 private resort could be to assist and collaborate (within the specific characteristics of required partnership) with CBT projects/ventures in 'close by' islands. Each resort will have its twin CBT projects.

This partnership and synergy could be beneficial to both: guests in the resort could spend a day (night) in the CBT venture as part of the travel package and guest at the CBT venture could visit and or use facilities of the resort (at agreed price/costs). Such a partnership could be established on a long-term basis. These options seem viable in the light of the fact that tourists, including luxury tourists, are more interested in social and environmental matters - because they look for unique experiences.

Guesthouses and other small-medium accommodation linked to surf-tourism or backpacking tourism segment could be included in CBT or excluded based on ownership and management structure. The dotted lines related to some of the connections to guesthouses indicate that guesthouses can or cannot be CBT based on the type of ownership, management and other characteristics specific to CBT. Thus, these accommodations can be linked to each other and to CBT accommodation and the CBT organization. The CBT organization should become the central coordinating and facilitating agency that assists in implementing and monitoring various CBT ventures and CBT related activities in their development effort. CBT organization should also assist 
CBT ventures when dealing with private sector firms in relation to partnership agreements. Government and the tourism sector can, in various specific ways, assist CBT ventures and the CBT organization to facilitate and coordinate the CBT sector, while education institutions should facilitate education and skill development to government staff, civil society, private sector entrepreneurs and community member involved, or wishing to be involved, in different ways in CBT. Figure 2 below shows the proposed tourism general framework for Maldives (Figure 1).

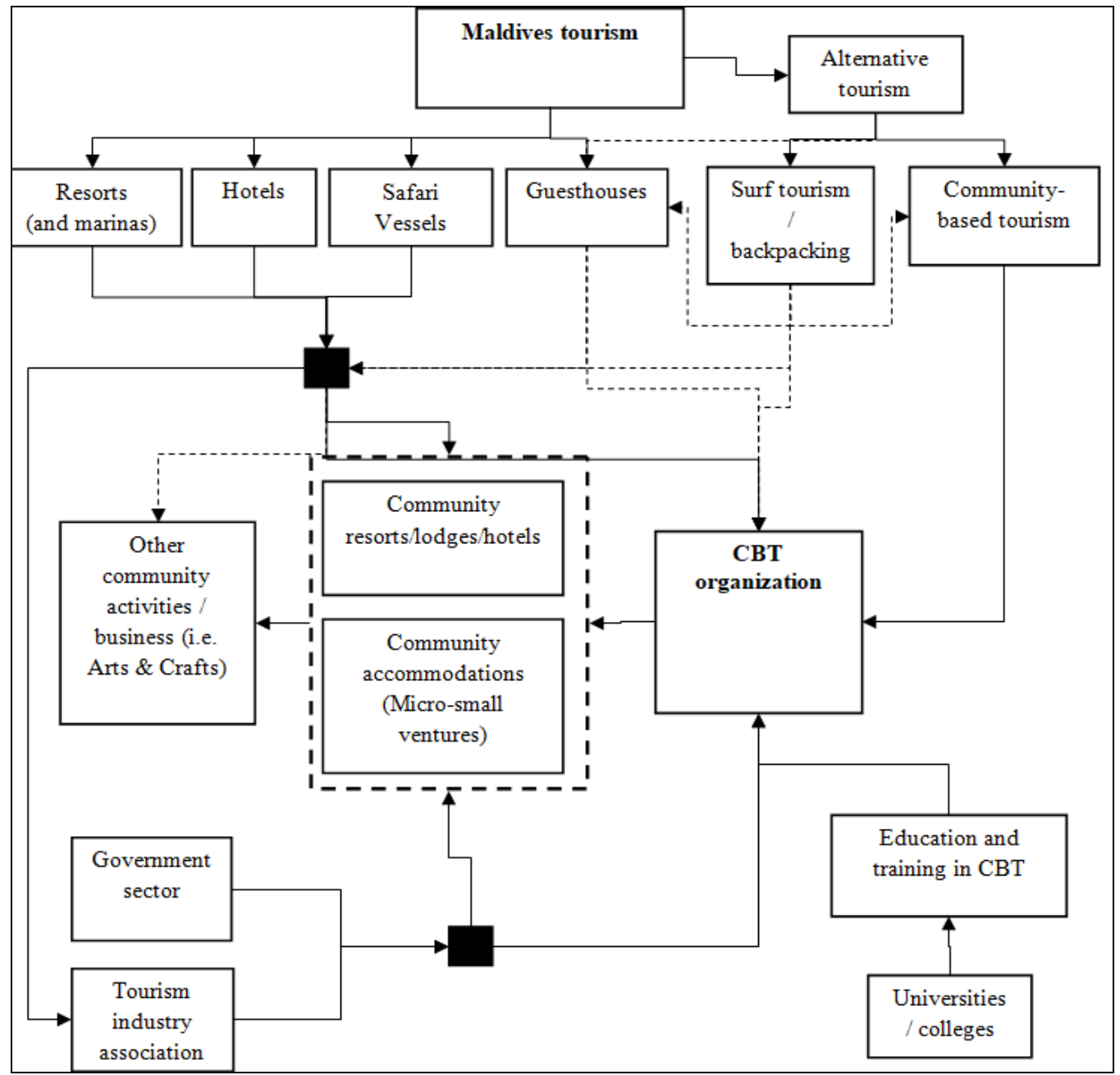

Figure 1. Proposed tourism general framework for Maldives

CBT can be developed in many islands/atoll so 'reverse' migration as new job opportunities will be developed in situ. Within this context five CBT development stages are envisaged (Table 2). Stage 1 serve to build the foundation of CBT milieu by preparing the specific legislation and capacity to implement it. Stages 2 is specifically dedicated to the establishment of the CBT organization, the entity that should become heavily involved in the operations of all organizations in the sector, by being the main protagonist, in facilitating and coordinating further stages and activities related to CBT development. 
Stage 3, involves undertaking awareness campaigns and further skill development at grassroots level should be implemented before reaching the 'practical' stage of mobilization and project planning. In these stages various projects proposals can be developed by various actors. Stage 4 involves verifying and where necessary assisting CBT projects/ventures in their planning stage. In stage 5 , the implementation process begins.

The various stages should not be taken as having fixed timeframes but it is envisaged that each stage will be an ongoing process. For instance, legislation can be regularly reviewed and amended; education and skills development should be on-going to involve new people and to keep knowledge being updated and so on.

Table 2. Proposed CBT development stages in Maldives

\begin{tabular}{|c|l|}
\hline Stages & \multicolumn{1}{|c|}{ Actions } \\
\hline 1 & $\begin{array}{l}\text { Legal framework } \\
\text { Education / capacity building }\end{array}$ \\
\hline 2 & Establishment of the CBT organization \\
\hline 3 & $\begin{array}{l}\text { Awareness } \\
\text { Further skill development at grassroots level }\end{array}$ \\
\hline 4 & Mobilization / project planning \\
\hline 5 & Implementation \\
\hline
\end{tabular}

The government's role remains fundamental and it should (must) play a key role in facilitating CBT. Government is also relevant in matters related to educational and skill development. In agreement, a research by Adam \& Urquhart, (2009) on IT capacity in relation to the tourisms sector in Maldives observed that it is important for government to put in place policies that facilitate national and workplace training in its long term plans including raising IT awareness and altering the negative perceptions people have about tourism. Education and capacity building in CBT is important and the introduction of a qualification in CBT at college and university level in order to advance CBT is here proposed as a necessity. This qualification should also be linked to lower level qualification on CBT to be offered at grassroots level. Because the dispersion of the population the use of Information Technology to deliver these courses and training can also be considered (Adam \& Urquhart, 2009). Specific attention needs to be placed in the local education system to advance and augment the knowledge related to all types of accommodation and to have a critical foundation on tourism development. It is not enough to produce a skilled workforce for menial jobs.

It is necessary to recognize the need to implement a curriculum that includes critical thinking, thus going beyond vocational skills oriented curriculum (Jugmohan et al., 2010). The need is to go beyond producing workers/employees but to advance and enhance the development of a well rooted local understanding of tourism in all its aspects and facilitate the flourishing of local owners and managers at all levels. Specifically, CBT (and also tourism SMMEs) curriculum should be introduced at various level of education in order to instill broader knowledge of tourism that goes beyond the private investment resort. CBT curriculum will also include issues related to the management of local cultural and natural resources as CBT is based on local resources and these need to be carefully and sustainably managed. In this context long-term sustainable management of the local natural environment becomes a fundamental requirement and should certainly be associated with the long-term resilience of the tourism sector but, importantly, also with the more comprehensive livelihood and well-being strategies of the local population. A full CBT qualification is therefore critical to advance CBT (including other alternative tourism forms) and increase awareness on sustainability. 


\section{CONCLUSION}

Tourism is a fundamental sector in many SIDS and Maldives is no exception. However, tourism growth in Maldives has been historically (and arguably still is) dominated by foreign controlled resorts. While tourism has assisted Maldives to develop economically, its benefits have not been fairly distributed. Thus, Maldives have various challenges linked to tourism. These are related to dependency of tourism on specific international and local actors, inequality in the control, ownership and benefit from tourism, the need to increase disadvantaged community and atolls (intended for poorest and social-economically and geographically marginalized section of the Maldivian population) involvement, and to decentralize and spread geographically tourism benefits to a greater number of atolls and islands. While Maldives have achieved some improvements in human development through tourism development, spatial development and income inequalities still remain. Based on this background, this paper proposes a model of tourism development and entrepreneurship that should shift conventional tourism towards CBT. This is done by using the accommodation sector as an example and based on various accommodation categories (arguably replicable to other tourism business such as restaurant) and, therefore, illustrating a possible tourism framework in relation to CBT. The tourism categories and tourism framework should shift the tourism industry towards a CBT milieu in order to overcome some of Maldives challenges such as inequality in the control, ownership and benefit from tourism, and so forth. This is not to say that private resorts and hotels should be eliminated tour court (this is not feasible, realistic and reasonable) a shift to reform the private resorts and hotels towards CBT principle and associate with CBT contexts is proposed. At the same time, this paper also advances the need to develop CBT itself.

The paper also indicated that education has a fundamental role in the process and a new CBT degree and curriculum should be introduced. The authors of this paper believe that the Maldives have enough resources and capacities to make tourism an industry that all Maldivian citizens benefit of. Different historical times need different approaches to development. The Maldives have been a pioneer in tourism with the approach 'of one island one resort'. Let the Maldives again be at the forefront - a trail blazer and innovator - of international tourism development approach by starting to shift towards a more locally controlled and equitable tourism sector anchored on CBT principles of local ownership and management, based on local resources and advancing equity and cooperation. Maldives could become the example to follow and enhance its image in the tourism sector and especially in the current tourism market in which tourists are increasingly looking for a tourism that is responsible, equitable and sustainable.

The shift in Maldives to CBT milieu should be seen in line with current and evolving tourism market trends and imperatives of the times. Further research seems certainly necessary to better investigate innovative approaches within which CBT principles can increase tourism development in Maldives (and elsewhere) in a way that enhances equity and redistribution of benefits, promotes community entrepreneurship, and protects local social and natural environments. Specifically, more research should be carried out on guesthouses and other possible CBT establishments present or that could be established in Maldives such as community resorts and micro and small CBT enterprises.

\section{REFERENCES}

Briguglio, L. \& Briguglio, M. (2004). Sustainable tourism in small islands the case of Malta. Retrieved 29 January 2018 from https://pdfs.semanticscholar.org/8807/5377890dda7858aaea6a10478e504e85boc7.pdf 
Burgos, A., Frédéric \& Mertens. (2017). Participatory management of community-based tourism: A network perspective. Community Development, no. 4, vol. 48, p. 546-565.

Giampiccoli, A. (2015). Community-based tourism: Origins and present trends, African Journal for Physical, Health Education. Recreation and Dance, no. 2, vol. 21, p. 675-687.

Giampiccoli, A., Saayman, M. \& Jugmohan, S. (2014). Developing community-based tourism in South Africa: Addressing the missing link, African Journal for Physical, Health Education, Recreation and Dance, no. 3:2, vol. 20. P. 1139-1161.

Kundur, S.K. (2012). Development of tourism in Maldives. International Journal of Scientific and Research Publications, no. 4 vol. 2, p. 1-5.

Leksakundilok, A. \& Hirsch, P. (2008). Community-based tourism in Thailand, in J. Connell \& B. Rugendyke (Eds.), Tourism at the grassroot. Villagers and visitors in the Asia-Pacific (pp. 214- 235), London, Routledge.

Mano, A.D., Mayer, V.F. \& Fratucci, A.C. (2017). Community-based Tourism in Santa Marta Favela: social, economic and cultural opportunities. Brazilian Journal of Tourism Research, 11(3), pp. 413-435.

Mearns, K. (2012). Community-based tourism and peace parks benefit local communities through conservation in Southern Africa. Acta Academica, no. 2, vol. 44, p. 70-87.

Mearns, K.F., lukhele, S.E. (2015). Addressing the operational challenges of community-based tourism in Swaziland. African Journal of Hospitality, Tourism and Leisure, no. 1, vol. 4, p. 1-13.

Mtapuri, O. \& Giampiccoli, A. (2016). Towards a comprehensive model of community-based tourism development. South African Geographical Journal, no. 1, vol. 98, p. 154-168.

Mtapuri, O. \& Giampiccoli, A. (2017). A conceptual coalescence: Towards Luxury Community-based Tourism. African Journal of Hospitality, Tourism and Leisure, no. 3. Vol. 6, p. 1-14.

Nagarjuna, G. (2015). Local Community Involvement in Tourism: A Content Analysis of Websites of Wildlife Resorts, Atna. Journal of Tourism Studies, no.1, vol. 10, p. 13-21.

Ndlovu, J., Nyakunu, E. \& Auala, S. (2011). Community based tourism in Twyfelfontein conservancy: Exploring local community's involvement. International Journal of Hospitality \& Tourism Systems, no. 2. Vol. 4, p. 38-46.

Novelli, M. \& Gebhardt, K. (2007). Community Based Tourism in Namibia: 'Reality Show' or 'Window Dressing'?' Current Issues in Tourism, no. 5, vol. 10, p. 443-479.

Rasoolimanesh, S.M. \& Jaafar, M. (2016). Community Participation toward Tourism Development and Conservation Program in Rural World Heritage Sites, in Butowski, L., (ed.) Tourism - From Empirical Research Towards Practical Application, pp. 1-14. London: InTech, Chapters published.

Sinclair-Maragh, G. \& Gursoy, D. (2015). Imperialism and tourism: The case of developing island countries. Annals of Tourism Research, 50, 143-158.

Tasci, A.D.S., Semrad, K.J. \& Yilmaz, S.S. (2013). Community based tourism finding the equilibrium in

Twining-Ward, L. \& Butler, R. (2002). Implementing STD on a Small Island: Development and Use of Sustainable Tourism Development Indicators in Samoa. Journal of Sustainable Tourism, no. 5, vol. 10, p. 363-387.

Vogt, C., Jordan, E., Grewe, N. \& Kruger, L. (2016). Collaborative tourism planning and subjective well-being in a small island destination. Journal of Destination Marketing \& Management, vol. 5, p. 36-43.

*** Asian Development Bank. (2015b). Maldives. Overcoming the challenges of a small island state. Country diagnostic study. Manila, Asian Development Bank.

*** Asian Development Bank., (2015a), Country Operations Business Plan. August 2015, Maldives 2016-2018, Asian Development Bank.

*** COMCEC context: Settin the Pathway for the Future, Ankara, COMCEC Coordination Office.

*** MOTAC, (2013a). Fourth tourism masterplan 2013-2017. Volume 1: strategic action plan. Ministry of Tourism Arts \& Culture. Malé.

*** MOTAC, (2013b). Fourth tourism masterplan 2013-2017. Volume 2: strategic action plan. Ministry of Tourism Arts \& Culture. Malé.

*** MTAC, (2011). Strategic human resource development plan for the tourism industry 2011-2015. Ministry of

Tourism, Arts and Culture, Male'.

*** MTRM, (2017). Tourism Yearbook 2017, Ministry of Tourism Republic of Maldives, Male'.

*** National Bureau of Statistics, 2017, Statistical pocketbook of Maldives 2017 Male', National Bureau of Statistics.

*** Trading Economics (2019). Maldives GDP, Available from https://tradingeconomics.com/maldives/gdp, accessed 14.10.2019.

*** UNDP, (no date), Tourism Adaptation Project (TAP): Increasing Climate Change Resilience of Maldives through Adaptation in the Tourism Sector, UNDP, Malé.

*** UNDP, (2016). Human Development Report 2016. Human Development for Everyone. Briefing note for countries on the 2016 Human Development Report, Maldives, UNDP.

Submitted:

09.08.2019
Revised:

27.03.2020
Accepted and published online 02.04 .2020 